Kaganga: Jurnal Pendidikan Sejarah dan Riset Sosial Humaniora

Volume 2, Nomor 1, Juni 2019

e-ISSN : 2598-4934

$p-I S S N$ : 2621-119X

DOI : https://doi.org/10.31539/kaganga.v2i1.673

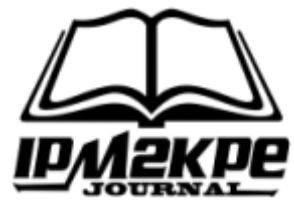

\title{
PENDIDIKAN KARAKTER BERBASIS BUDAYA LOKAL TAPIS LAMPUNG SEBAGAI UPAYA MEMPERKUAT IDENTITAS BANGSA
}

\author{
Isbandiyah $^{1}$, Supriyanto ${ }^{2}$ \\ STKIP-PGRI Lubuklinggau ${ }^{1,2}$ \\ isbandiyah@stkippgri-lubuklinggau.ac.id ${ }^{1}$
}

\begin{abstract}
ABSTRAK
Tujuan dari penelitian ini adalah untuk menganalisis nilai-nilai karakter Tapis Lampung sebagai upaya memperkuat identitas bangsa Indonesia. Adapun metode yang digunakan adalah metode kualitatif dengan pendekatan etnografi. Teknik pengumpulan datanya menggunakan studi kepustakaan dan model analisis yang digunakan adalah model Critical Discourse Analysis (CDA) atau analisis wacana kritis. Hasil penelitian didapatkan kain Tapis dibuat dengan sistem sulam, menggunakan benang kapas dan benang perak atau emas serta dengan motif hiasan bahan sugi. Kain Tapis biasanya dipakai oleh para gadis dan wanita suku Lampung, sebagai perlengkapan upacara adat, keagamaan, dan perkawinan. Dalam Tapis tersimpan nilai-nilai hidup atau nilai karakter yang berkembang dalam masyarakat Lampung. Nilai-nilai karakter tersebut diantaranya adalah nilai sakral, nilai stratifikasi sosial, nilai sejarah dan pemahaman terhadap alam, nilai kreativitas dan inklusivitas, nilai ekonomis, nilai kerjasama, dan nilai ketekunan, ketelitian, dan kesabaran. Kain Tapis Lampung merupakan salah satu identitas bangsa Indonesiayang tidak dimiliki oleh bangsa lain. Oleh karena itu, sebagai upaya memperkuat identitas bangsa, Kain Tapis Lampung diperkenalkan pada masyarakat internasional. Berdasarkan hasil analisis dari berbagai sumber, dapat disimpulkan bahwa Tapis merupakan salah satu bentuk pencapaian peradaban masyarakat Lampung
\end{abstract}

Kata Kunci: Nilai Karakter, Tapis Lampung, Identitas Bangsa

\begin{abstract}
The purpose of this study is to analyze the values of the character of Lampung Tapis as an effort to strengthen the identity of the Indonesian nation. The method used is a qualitative method with an ethnographic approach. The data collection technique uses library studies and the analysis model used is the Critical Discourse Analysis (CDA) model or critical discourse analysis. The results showed that Tapis fabric was made with a embroidery system, using cotton yarn and silver or gold thread and with decorative motifs of ingredients. Tapis cloth is usually worn by Lampung tribal girls and women, as supplies for traditional, religious and marriage ceremonies. In Tapis, the values of life or character values are developed in Lampung society. These character values include sacred values, social stratification values, historical values and understanding of nature, values of creativity and inclusiveness, economic value, value of cooperation, and values
\end{abstract}


of perseverance, thoroughness and patience. Lampung Tapis cloth is one of the national identities of Indonesia which is not owned by other nations. Therefore, as an effort to strengthen the national identity, Lampung Tapis Fabrics were introduced to the international community. Based on the results of analysis from various sources, it can be concluded that Tapis is one form of achievement of Lampung society civilization

\section{Keywords: Character Value, Lampung Filter, National Identity}

\section{PENDAHULUAN}

Bangsa Indonesia dengan bermacam aneka ragam corak, bentuk dan sifat kebudayaan daerah yang memiliki berbagai potensi bagi pengembangan nilai-nilai budayanya merupakan sumber kekayaan bangsa. Lampung, sebagai salah satu wilayah yang terdapat di ujung selatan pulau Sumatera, memiliki warisan budaya yang telah melahirkan benda-benda yang bernilai tinggi, benda-benda budaya tersebut merupakan hasil karya cipta masa lampau yang digunakan untuk memenuhi kebutuhan hidup masyarakat.

Namun, peninggalan budaya tersebut semakin langka, berkurang, bahkan mulai hilang di masyarakat, karena terdesak oleh pengaruh budaya yang berkembang dimasa sekarang. Jika kebudayan tersebut dibiarkan terus menerus maka dikhawatirkan kepunahannya. Maka dari sinilah kita sebagai bangsa Indonesia harus mempunyai rasa memiliki dengan adanya kebudayaan daerah, yaitu dengn cara melestarikan hasil-hasil budaya daerah kita.

Salah satu warisan budaya Lampung yang perlu dilestarikan adalah Tapis. Menurut Lestari, dkk. (1999) "Tapis adalah sejenis kain sarung yang digunakan oleh masyarakat Lampung terutama oleh para gadis dan wanita suku Lampung. Kain ini memiliki ragam hias dari setiap jenisnya. Ragam hias pada kain Tapis dibuat dengan cara menenun dan menggunakan benang emas atau perak."

Fungsi dari kain tenun tapissendiri adalah sebagai simbol yang terkandung pada lambang yang menjadi ragam hias motifnya. Pada mulanya, ragam hias yang dilukiskan pada pakaian tenun umumnya mempunyai arti atau bentuk abstrak dari satu objek. Kain tenun tapismerupakan perangkat yang memiliki makna beraneka ragam yang berhubungan dengan kepercayaan, perasaan sakral dan pemuasan akan cita rasa kaindahan.

TapisLampung termasuk kerajian tradisional karena peralatan yang digunakan dalam membuat kain dasar dan motif-motif hiasnya masih sederhana. Menurut Sujadi (2012) bahwa "Tapis merupakan kerajinan tradisional masyarakat dalam menyelaraskan antara kehidupan mereka, lingkungan, dan Sang Pencipta Alam Semesta."Hal senada juga diungapkan oleh Hamy dan Sutyawan (2011), "Tapismerupakan kerajinan tradisional masyarakat Lampung yang diajarkan secara turun temurun dan lahir sebagai "saranan" demi menyelaraskan kehidupan masyarakat dengan lingkungan sekitar maupun sang pencipta."

Dengan demikian dapat penulis jelaskan, bahwa tapis Lampung merupakan kerajinan tradisional masyarakat Lampung dalam bentuk kain sarung, yang menyelaraskan kehidupan masyarakat Lampung, baik 
dengan lingkungannya maupun dengan penciptaan alam semesta. Kain tapis ini dibuat dengan sistem sulam, menggunakan benang kapas dan benang perak atau emas serta dengan motif atau hiasan bahan sugi. Kain tapis biasanya dipakai oleh para gadis dan wanita suku Lampung, sebagai perlengkapan upacara adat, keagamaan dan perkawinan, akan tetapi tapisbanyak juga diproduksi sebagai komoditi yang mempunyai nilai ekonomi yang cukup tinggi.

Saat ini kerajinan tapistelah banyak diminati oleh berbagai masyarakat Lampung. Perkembangan tapisini dapat dilihat dari beberapa segi, yakni segi sosial, ekonomi, dan mengurangi tingkat pengangguran. Dari segi sosial masyarakat Lampung memiliki simbol atau keunikan ragam hias yang dapat digunakan sebagai nilai estetika daerah Lampung, sedangkan dari segi ekonomi kerajinan tapis dapat meningkatkan perekonomian dan dapat menambah lapangan kerja bagi masyarakat Lampung. Perkembangan ragam hiasnya yaitu menghasilkan desain yang menarik dan motif maupun bentuk yang sudah dimodifikasi. Untuk perkembangan bahan, sekarang banyak yang menggunakan tenun yang sudah jadi dan menggunakan benang emas, sehingga tinggal menyulam.Sementara hasil karya yang diciptakan melalui kerajinan tapisyang sudah banyak dipasarkan, yaitu sarung, hiasan dinding, taplak meja, tas, dan sebagainya.

Berdasarkan uraian di atas, perlu mengkaji lebih dalam lagi mengenai budaya lokal Tapis Lampung, karena di dalamnya terdapat nilai-nilai karakter yang perlu dikembangkan, sehingga nilai-nilai karakter yang terdapat dalam budaya lokal Tapis Lampung dapat dijadikan sebagai identitas bangsa. Dengan demikian, penulis membuat sebuah judul "Pendidikan Karakter Berbasis Budaya Lokal Tapis Lampung Sebagai Upaya Memperkuat Identitas Bangsa."

\section{METODE PENELITIAN}

Metode yang digunakan dalam penulisan ini yaitu metode kualitatif dengan pendekatan studi etnografi. Studi etnografi merupakan salah satu pendekatan dalam penelitian kualitatif yang berusaha untuk mengkaji tentang kebudayaan yang ada pada sutu kelompok tertentu. Pendapat tersebut sejalan dengan Saryono dan Anggraeni (2011) yang menyatakan bahwa studi etnografi berusaha mengungkap budaya yang diterapkan dalam suatu kelompok. Adapun tujuan penggunaan studi etnografi adalah untuk mengungkapkan berbagai makna dan menjelaskan pemahamaan baru mengenai objek yang diteliti. Objek yang diteliti dalam hal ini adalah budaya lokal Tapis Lampung.

Teknik pengumpulan data dalam penelitian ini yaitu menggunakan kajian pustaka, yaitu dengan mengumpulkan berbagai sumber referensi seperti buku, artikel, surat kabar yang berkaitan dengan objek yang diteliti. Teknik penggumpulan data yang lainnya yaitu berupa foto/gambar.

Salah satu model analisis data yang digunakan dalam penulisan ini yaitu model Critical Discourse Analysis (CDA) atau analisis wacana kritis. Adapun cara kerja model CDA menurut Aminuddin yang dikutip oleh Fatchan (2009), diantaranya sebagai berikut:

Memahami untaian data sebagai teks secara analitis; Menghubungkan representasi makna kata-kata maupun kalimat sebagai unsur pembeda teks secara analitis; Menentukan pengertian atau value yang termuat dalam teks 
secara kontekstual dan intersekstual sesuai dengan pola pra-anggapan, assumsi, maupun konsep teoritik yang digunakan peneliti; dan melakukan komparasi antara kesimpulan dan justifikasi yang dibuahkan dengan konkretisisasi data maupun dengan kenyataan konkret sebagaimana terdapat dalam dunia pengalaman peneliti.

\section{HASIL DAN PEMBAHASAN Pendidikan Karakter}

Akar dari semua tindakan yang jahat dan buruk, tindakan kejahatan, terletak pada hilangnya karakter. Semestinya karakter ada di dalam diri setiap orang sebagai benteng agar tidak melakukan tindakan yang menyimpang. Karena karakter dapat memberikan kemampuan kepada sekelompok orang untuk hidup bersama dalam kedamaian dan kebaikan. Seperti yang diungkapkan oleh Samani dan Hariyanto (2012) "Karakter yang kuat adalah sandangan fundamental yang memberikan kemampuan kepada populasi manusia untuk hidup bersama dalam kedamaian serta membentuk dunia yang dipenuhi dengan kebaikan dan kebajikan, yang bebas dari kekerasan dan tindakantindakan yang tidak bermoral."

Berdasarkan pendapat di atas, karakter dimaknai sebagai cara berpikir dan berperilaku yang khas setiap individu untuk hidup dan bekerja sama, baik dalam keluarga, masyarakat maupun bangsa dan negara. Individu yang berkarakter baik adalah individu yang dapat membuat keputusandan siap mempertanggungjawabkan setiap akibat dari hasil keputusannya. Karakter tidak diwariskan, tetapi sesuatu yang dibangun secara berkesinambungan dari hari ke hari melalui pemikiran dan perbuatan. Hal ini diwujudkan melalui pendidikan, yaitu pendidikan karakter.

Menurut Lickona yang dikutip oleh Gunawan (2012) "Pendidikan karakter adalah pendidikan untuk membentuk kepribadian seseorang melalui pendidikan budi pekerti, yang hasilnya terlihat dalam tindakan nyata seseorang, yaitu tingkah laku yang baik, jujur, bertanggungjawab, menghormati hak orang lain, kerja keras, toleransi, dan sebagainya." Menurut Aunillah (2011) "Pendidikan karakter adalah sebuah sistem yang menanamkan nilai-nilai karakter pada peserta didik, yang mengandung komponen pengetahuan, kesadaran individu, tekad, serta adanya kemauan dan tindakan untuk melaksanakan nilainilai, baik terhadap Tuhan Yang Maha Esa, diri sendiri, sesama manusia, lingkungan, maupun bangsa, sehingga akan terwujud insan kamil." Megawangi (2004) menyatakan bahwa "Pendidikan karakter adalah sebuah usaha sadar untuk mendidik peserta didik agar dapat mengambil keputusan bijak dan memperhatikannya dalam kehidupan sehari-hari, sehingga mereka dapat memberikan kontribusi yang positif kepada lingkungannya."

Berdasarkan pendapat tersebut, yang dimaksud dengan pendidikan karakter adalah suatu proses dalam menanamkan nilai-nilai karakter pada anak yang dirangkai dalam bentuk sikap, perilaku, motivasi, dan keterampilan. Jadi, pendidikan karakter adalah hal yang sangat penting untuk perkembangan anak. Apabila dikaitkan dengan makalah ini, maka pendidikan karakter adalah nilai-nilai yang terkandung dalam budaya lokal kain Tapis Lampung dalam rangka memperkuat identitas bangsa. Dengan demikian, perlu terus mengambangkan pendidikan karakter yang berbasis 
budaya lokal, sehingga semakin terlihat dan kuatnya identitas bangsa.

Pendidikan karakter memiliki beberapa tujuan yang ingin dicapai. Menurut Sulistyowati (2012) Tujuan pendidikan karakter, diantaranya:

Mengembangkan potensi kalbu/ nurani/ afektif siswa sebagai manusia dan warga negara yang memiliki nilai-nilai budaya dan karakter bangsa; mengembangkan kebiasaan dan perilaku siswa yang terpuji dan sejalan dengan nilai-nilai universal dan tradisi budaya bangsa yang religius; Menanamkan jiwa kepemimpinan dan tanggungjawab siswa sebagai generasi penerus bangsa; Mengembangkan kemampuan siswa menjadi manusia yang mandiri, kreatif, berwawasan kebangsaan; dan mengembangkan lingkungan kehidupan sekolah sebagai lingkungan belajar yang aman, jujur, penuh kreativitas dan persahabatan, serta kebangsaan yang tinggi dan penuh kekuatan.

Berdasarkan pendapat tersebut tujuan pendidikan karakter sangat mulia dan bermanfaat untuk manusia dan juga untuk lingkungan sekitar. Hal ini karena tujuan pendidikan karakter mengarah pada pengembangan kemampuan dan perilaku seseorang agar menjadi lebih baik serta memiliki nilai guna yang tinggi.

Untuk mengetahui keberhasilan pelaksanaan pendidikan karakter, dapat dilihat dari ciri-ciri pendidikan karakter. Menurut Adisusilo (2012) ada empat ciri dasar pendidikan karakter.

Keteraturan interior di mana setiap tindakan diukur berdasarkan seperangkat nilai. Nilai menjadi pedoman normative setiap tindakan; Koherensi yang memberi keberanian, yang membuat seseorang teguh pada perinsip, tidak mudah terombangambing pada situasi. Koherensi ini merupakan dasar yang membangun rasa percaya satu sama lain, tanpa kohorensi maka kredibilitas seseorang akan runtuh; Otonomi maksudnya seseorang menginternalisasikan nilainilai dari luar sehingga menjadi nilainilai pribadi, menjadi sifat yang melekat, melalui keputusan bebas tanpa paksaan dari orang lain; dan Keteguhan dan kesetiaan. Keteguhan merupakan daya tahan seseorang guna menginginkan apa yang dipandang baik, dan kesetiaan merupakan dasar bagi penghormatan atas komitmen yang dipilih.

Pendapat di atas menunjukkan bahwa terlaksananya pendidikan karakter dapat dilihat dari ciri-cirinya, diantaranya adanya tindakan yang sesuai dengan nilai-nilai karakter, munculnya orang yang teguh pada prinsip dan tidak mudah terombangambing pada situasi, adanya internalisasi nilai-nilai karakter hingga menjadi sifat/watak yang melekat pada diri seseorang, dan adanya seseorang yang memiliki daya tahan dan komitmen yang tinggi. Jika semua ciriciri pendidikan karakter sudah melekat dalam diri seseorang, maka pendidikan karakter telah terlaksana dengan baik.

\section{Budaya Lokal Tapis Lampung}

Pendidikan dan kebudayaan memiliki keterkaitan yang sangat kuat. Pendidikan tidak dapat dipisahkan dengan kebudayaan. Tanpa proses pendidikan tidak mungkin kebudayaan itu berlangsung dan berkembang. Proses pendidikan tidak lebih dari sebagai proses transmisi kebudayaan.Sumaatmadja (2002) menyatakan bahwa "Hubungan antara pendidikan dan kebudayaan paling tidak terdapat kata-kata kunci, yaitu "Pendidikan merupakan akulturasi (pembudayaan), institusionalisasi, transfer, imparting (memberikan, 
menggambarkan), explain, justity, dan directing (mengarahkan)."

Dalam perspektif Antropologi, pendidikan merupakan transformasi sistem sosial budaya dari satu generasi ke generasi lainnya dalam suatu masyarakat. Tilaar (2000) menjelaskan bahwa "Pendidikan merupakan proses pembudayaan". Dengan kata lain, pendidikan dan kebudayaan memiliki hubungan yang tidak dapat dipisahkan. Ketika berbicara tentang pendidikan, maka kebudayaan pun ikut serta di dalamnya. Tidak ada kebudayaan tanpa pendidikan dan begitu pula praktik pendidikan selalu berada di dalam lingkup kebudayaan.

Menurut Tylor yang dikutip oleh Ratna (2005) "Kebudayaan adalah keseluruhan aktivitas manusia, termasuk pengetahuan, kepercayaan, seni, moral, hukum, adat-istiadat, dan kebiasaan-kebiasaan lain." Sementara Harris (1999) menyebutkan "Kebudayaan yaitu seluruh aspek kehidupan manusia dalam masyarakat, yang diperoleh dengan cara belajar, termasuk pikiran dan tingkah laku".

Berdasarkan pendapat di atas, kebudayaan dipandang sebagai manifestasi kehidupan setiap orang atau kelompok orang yang selalu mengubah alam. Kebudayaan merupakan usaha manusia, perjuangan setiap orang atau kelompok dalam menentukan hari depannya. Budaya lahir karena kemampuan manusia mensiasati lingkungan hidupnya agar tetap layak untuk ditinggali waktu demi waktu.

Menurut Setiyawan (2012) "Budaya lokal (juga sering disebut budaya daerah) merupakan istilah yang biasanya digunakan untuk membedakan suatu budaya dari budaya nasional (Indonesia) dan budaya global. Budaya lokal adalah budaya yang dimiliki oleh masyarakat yang menempati lokalitas atau daerah tertentu yang berbeda dari budaya yang dimiliki oleh masyarakat yang berada di tempat yang lain."

Permendagri Nomor 39 Tahun 2007 Pasal 1 mendefinisikan "Budaya daerah sebagai suatu sistem nilai yang dianut oleh komunitas/kelompok masyarakat tertentu di daerah, yang diyakini akan dapat memenuhi harapan-harapan warga masyarakatnya dan di dalamnya terdapat nilai-nilai, sikap tata cara masyarakat yang diyakini dapat memenuhi kehidupan warga masyarakatnya".

Dengan demikian, budaya lokal ialah pengetahuan lokal yang sudah sedemikian menyatu dengan sistem kepercayaan, norma, dan budaya, serta diekspresikan dalam tradisi dan mitos yang dianut dalam jangka waktu yang lama, maka kearifan lokal merupakan sesuatu yang berkaitan secara spesifik dengan budaya tertentu (budaya lokal) dan mencerminkan cara hidup suatu masyarakat tertentu (masyarakat lokal). Dengan kata lain, kearifan lokal bersemayam pada budaya lokal (local culture).

Tapis Lampung merupakan salah satu budaya lokal yang terbentuk melalui tahapan dan periodisasi waktu yang panjang. Dalam proses perjalanannya terjadi berbagai penyempurnaan, baik dari aspek teknik dan keterampilan pembuatan, bentuk motif yang diterapkan, dan metode penerapan motif pada kain dasar tapis, menyesuaikan dengan perubahan dan perkembangan zaman. Perjalanan sejarah perkembangan terbentuknya ragam hias, kain tapis Lampung mendapat berbagai pengaruh kebudayan lain, seiring dengan terjalinnya kontak, interaksi, dan komunikasi masyarakat adat Lampung dengan kebudayaan luar. Kebudayaan yang memberikan pengaruh pada 
pembentukan gaya seni hias kain tapis antara lain, kebudayan dongson dari daratan Asia, Hindu-Buddha, Islam, dan Eropa.

Pembentukan kain Tapis melalui proses yang panjang, akulturasi terjadi antara unsur-unsur hias kebudayaan asing dengan unsur-unsur hias lama. Unsur-unsur asing yang datang tidak menghilangkan unsurunsur lama, akan tetapi semakin memperkaya corak, ragam, dan gaya yang sudah ada. Berbagai kebudayaan tersebut terpadu dan terintegrasi dalam satu konsep utuh yang tidak dapat dipisahkan dan melahirkan corak baru yang unik dan khas.

Kain Tapis bagi masyarakat adat Lampung memiliki makna simbolis sebagai lambang kesucian yang dapat melindungi pemakainya dari segala kotoran dari luar. Selain itu, dalam pemakaiannya kain tapis juga melambangkan status sosial pemakainya. Makna simbolis kain tapis terdapat pada kesatuan utuh bentuk motif yang diterapkan, serta bidang warna kain dasar sebagai wujud kepercayaan yang melambangkan kebesaran Pencipta Alam. Kain tapis merupakan pakaian resmi masyarakat adat Lampung dalam berbagai upacara adat dan keagamaan, dan merupakan perangkat adat yang serupa pusaka keluarga.

Susunan masyarakat yang bertingkat-tingkat mengkondisikan adanya aturan yang mengatur pemakaian kain tapis sebagai busana adat yang menyesuaikan status sosialnya dalam masyarakat. Aturan yang berlaku tersebut juga disertai hukuman atau sanksi adat (cepalo) bagi anggota masyarakat yang melanggarnya. Namun, dalam rentang perjalanannya, kain tapis tidak hanya menunjukkan suatu proses kontinum kelangsungannya, tetapi juga menampakkan terjadinya perubahan dan pengembangan dalam banyak aspek, seperti pada aspek fungsinya kain tapis berubah dari benda sakral yang terkait erat dengan adat dan kepercayaan masyarakat Lampung berubah menjadi benda profan dan sekuler yang berfungsi untuk komoditi pasar. Pada aspek produknya kain tapis tidak hanya berupa kain sarung adat, tetapi sudah mengalami modifikasi dan diversifikasi, sehingga tercipta berbagai produk seni kerajinan kain Tapis seperti, busana pesta, busana muslim, hiasan dinding, kaligrafi, partisi ruangan, perlengkapan kamar tidur, tas, dompet, kopiah, tempat tisu, dan sebagainya.

Pada aspek bentuk motif yang diterapkan tidak terjadi perubahan frontal, secara umum bentuk motifnya masih sama hanya terjadi perubahan seiring perubahan bentuk produk yang disertai pengembangan, modifikasi, variasi, penyederhanaan, dan sedikit penambahan. Perubahan signifikan terjadi pada penghilangan makna simbolis-filosofis yang terkandung di dalamnya. Motif kain tapis sekarang hanya dilihat dari aspek keindahannya semata.

Perubahan yang terjadi pada kain tapis Lampung terjadi seiring dengan perubahan masyarakat pendukungnya, seperti adanya interpretasi dan persepsi masyarakat Lampung terhadap kain tapis, keterbukaan masyarakat Lampung terhadap berbagai inovasi, ide-ide, dan kreasi baru yang tercermin pada sifat dan watak nemui nyimah, dan nengah nyappur. Kecintaan, keinginan, dan sikap progresif para perajin kain tapis yang didukung bakat seni dan keterampilan teknik yang diturunkan generasi sebelumnya untuk melestarikan, mempertahankan, dan 
mengembangkan seni kerajinan kain tapis.

Faktor eksternal yang mendorong terjadinya perubahan seni kerajinan kain Tapis Lampung, selain berkembangnya dunia pariwisata daerah Lampung adalah adanya lembaga atau institusi pemerintah maupun swasta di Lampung yang berusaha mengembangkan seni kerajinan kain tapis dengan melakukan berbagai usaha, seperti program pelatihan, penyuluhan, dan pembinaan untuk dapat meningkatkan kemampuan teknis, jiwa kewirausahaan, maupun manajemen usaha para perajin kain tapis. Pemerintah juga telah mengambil kebijakan penting dengan menciptakan lingkungan usaha yang kondusif dan memberikan kemudahan dalam bidang produksi, permodalan, distribusi, dan pemasaran.

Pembubaran lembaga adat Lampung (kepunyimbangan) oleh pemerintah juga ikut mendorong perubahan yang terjadi pada kain tapis. Dengan berubahnya struktur pemerintahan, maka lembaga dan organisasi sosial dalam masyarakat adat tidak lagi memiliki legitimasi. Lembaga adat (kepunyimbangan) yang berfungsi sebagai pagar sekaligus kontrol dalam rangka melindungi stabilitas masyarakat tidak berfungsi lagi sebagaimana mestinya. Namun akan lebih baik seandainya keputusan pemerintah tentang penghapusan lembaga adat ditinjau kembali, karena adanya lembaga tersebut akan semakin memperkokoh eksistensi kain tapis Lampung.

Selain dampak sosial budaya yang berhasil melestarikan dan mempertahankan kelangsungan seni kerajinan kain tapis, perubahan yang terjadi pada kain tapis juga mempunyai dampak sosial ekonomi. Dampak perubahan kain tapis dari aspek ekonomi sudah jelas pada meningkatnya penghasilan para perajin.

\section{Identitas Bangsa}

Setiap negara yang merdeka dan berdaulat sudah dapat dipastikan berupaya memiliki identitas nasional, agar negara tersebut dapat dikenal oleh negara-bangsa lain, dapat dibedakan dengan bangsa lain. Identitas nasional mampu menjaga eksistensi dan kelangsungan hidup negara-bangsa. Negara-bangsa memiliki kewibawaan dan kehormatan sebagai bangsa yang sejajar dengan bangsa lain serta akan menyatukan bangsa yang bersangkutan. Oleh karena itu, identitas nasional menjadi sangat penting bagi bangsa Indonesia. Menurut Samaludin (2017) "Identitas nasional adalahsuatu jati diri yang khas dimiliki oleh suatu bangsa dan tapi tidak dimiliki bangsa lain. Dengan kata lain,dentitas nasional adalah kumpulan nilai-nilai budaya yang tumbuh dan berkembang dalam berbagai aspek kehidupan dari ratusan suku yang dihimpun dalam satu kesatuan Indonesia menjadi kebudayaan nasional dengan acuan pancasila dan Bhineka Tunggal Ika sebagai dasa dan arah pengembangannya."

Sementara Kohn

menyatakan bahwa "Identitas memiliki arti sebagai ciri yang dimiliki setiap pihak, yang dimaksud sebagai suatu pembeda atau pembanding dengan pihak yang lain. Sedangkan nasional atau nasionalisme memiliki arti sutau paham, yang berpendapat bahwa kesetiaan tertinggi individu harus diserahkan kepada negara kebangsaan." Selanjutnya menurut Kaelan (2010) "Identitas nasional adalah suatu ciri yang dimiliki oleh suatu bangsa yang secara filosofis membedakan bangsa tersebut dengan bangsa lain." 
Dengan demikian, identitas bangsa merupakan ciri yang dimiliki oleh setiap bangsa, yang diupayakan untuk dipublikasikan agar dapat dikenal oleh bangsa lain, sehingga dapat dilihat perbedaannya dengan bangsa lain. Identitas suatu bangsa tidak hanya melibatkan individu saja, melainkan juga melibatkan seluruh kelompok masyarakat. Identitas bangsa disebut juga sebagai jati diri bangsa. Dalam hal ini Isbandiyah (2015) menyatakan bahwa "Jatidiri bangsa adalah nilai-nilai luhur yang menentukan kepribadian suatu bangsa, sehingga diakui oleh bangsa lain sebagai suatu kepribadian yang berbeda. Kepribadian atau jatidiri suatu bangsa diadopsi dari nilai-nilai budaya dan nilai-nilai agama yang diyakini kebenarannya. Jika ada orang yang mengatakan bahwa bangsa Indonesia adalah bangsa yang beradab, bangsa yang berbudaya, bangsa yang beretika, maka itulah yang dikatakan kepribadian atau jatidiri bangsa Indonesia. Jati diri bangsa itu terbentuk karena adanya rasa bahwa kita sebagai bangsa Indonesia mengalami pengalaman bersama, sejarah yang sama, dan penderitaan yang sama. Jati diri bangsa akan nampak dalam karakter bangsa yang merupakan perwujudan dari nilai-nilai luhur bangsa."

Berdasarkan beberapa pendapat di atas, identitas bangsa merupakan nilai-nilai luhur yang dijadikan penentu kepribadian suatu bangsa sebagai ciri khas dari bangsa tersebut, juga untuk membedakan dengan bangsa lain. Identitas bangsa terbentuk dari karakter masyarakatnya dan kebudayaan yang ada didalamnya. Identitas melekat pada kelompok-kelompok besar yang diikat oleh kesamaan-kesamaan, seperti budaya, agama, bahasa dan juga non fisik seperti keinginan, cita-cita dan tujuan. Secara spesifik inti dari identitas bangsa adalah pengakuan terhadap suatu bangsa berdasarkan atas serangkaian ciri-ciri yang merupakan suatu kesatuan bulat dan menyeluruh menggambarkan suatu bangsa.

\section{Nilai-Nilai Karakter dan Budaya dalam Tapis Lampung}

Kain Tapis merupakan salah satu bentuk pencapaian peradaban Lampung. Di dalam Kain Tapis tersimpan nilai-nilai yang hidup dan berkembang dalam masyarakat Lampung. Nilai-nilai tersebut di antaranya adalah nilai sakral, nilai stratifikasi sosial, nilai sejarah dan pemahaman terhadap alam, nilai kreativitas dan inklusivitas, nilai ekonomis, nilai kerjasama, dan nilai ketekunan, ketelitian, dan kesabaran. Nilai-nilai tersebut diuraikan di bawah ini:

Pertama, nilai sakral. Kain Tapis biasanya dipakai dalam setiap upacara adat dan keagamaan, dan merupakan perangkat adat yang serupa pusaka keluarga. Kain ini bagi masyarakat Lampung merupakan simbol kesucian. Kain ini diyakini dapat melindungi pemakainya dari segala macam kotoran luar. Sebagai simbol kesucian, maka proses pembuatan Kain Tapis dilakukan secara cermat dan melalui tahapantahapan yang cukup rumit. Nilai-nilai sakral ini juga dapat dilihat pada bentuk motifnya yang mengandung makna-makna simbolis-filosofis, seperti motif pohon hayat dan bangunan yang berisikan roh manusia, dan adanya aturan-aturan kapan dan pada acara apa kain ini digunakan.

Kedua, nilai stratifikasi sosial. Kain ini juga berfungsi sebagai penanda status sosial seseorang. Artinya, dengan melihat Kain Tapis yang digunakan, maka kita akan 
mengetahui status sosial orang tersebut. Misalnya dalam upacara pengambilan gelar adat ada orang yang menggunakaan Tapis Tuho, maka orang tersebut dipastikan mempunyai status sosial yang tinggi. Menurut aturan adat, yang berhak menggunakan Tapis Tuhoadalah isteri dari orang yang sedang mengambil gelar sultan, orang tua (mepahao) yang sedang mengambil gelar sultan, dan atau istri sultan yang menghadiri upacara pengambilan gelar kerabat dekatnya.

Ketiga, nilai sejarah dan pemahaman terhadap alam. Dengan melihat motif kain tapis, maka kita akan mengetahui sejarah perkembangan masyarakat Lampung, dan sekaligus mengetahui kondisi alam di mana masyarakat Lampung hidup. Alam bagi para pengrajin tapis merupakan sumber inspirasi bagi penciptaan motif-motif. Misalnya penggunaan beragam jenis transportasi laut telah memberi ide penggunaan motif hias berupa aneka macam bentuk kapal. Dengan melihat motif-motif kapal tersebut, maka kita akan mengetahui bahwa sejak zaman dahulu masyarakat Lampung telah mengenal beragam bentuk dan konstruksi kapal.

Keempat, nilai kreativitas dan inklusivitas. Ragam hias dan motif pada kain tapis merupakan bukti dari kreativitas masyarakat Lampung. Mereka menghayati alam dan "melukiskannya" dalam kain. Selain itu, Kain Tapis juga merupakan manifestasi dari akulturasi antara antara unsur-unsur hias kebudayaan setempat (lama) dengan unsur-unsur hias kebudayaan lain (baru). Terjadinya akulturasi ini merupakan sifat kebudayaan Lampung yang inklusif. Para pendahulu orang Lampung mengajarkan kepada kita agar tidak merubah khazanah kebudayaan sendiri dan merubahnya dengan kebudayaan orang lain, tetapi menjadikan kebudayaan lain sebagai sumber inspirasi untuk memperkaya kebudayaan sendiri.

Kelima, nilai ekonomi. Dalam paradigma ekonomi kreatif, maka kreativitas mempunyai nilai ekonomi tinggi. Hal inilah yang nampaknya mulai disadari oleh masyarakat Lampung. Dengan kreativitas dan inovasi, misalnya menciptakan Kain Tapis yang sesuai kebutuhan pasar, maka Kain Tapis dapat menjadi sumber ekonomi bagi masyarakat Lampung. Sebagai sumber ekonomi, maka Kain Tapis tidak hanya memberikan kebanggaan secara budaya (imateriil) kepada masyarakat, tetapi juga yang bersifat ekonomi (materiil). Namun pengembangan nilai ekonomis kain tapis harus dilakukan secara hati-hati dan cermat agar kain tapis tidak tercabut dari akar lokalitasnya.

Keenam, nilai kerjasama tercermin dari proses pembuatan tapis itu sendiri. Untuk dapat menghasilkan sehelai tapis secara utuh tidak dapat dilakukan oleh seorang individu saja, tetapi harus bekerja sama dengan orang lain agar tidak memakan waktu lama. Misalnya, ada yang bekerja membuat benang, membuat motif dan ragam hias, menenun kain, dan ada pula yang menyulam ragam hiasnya.Ketujuh, nilai ketekunan, ketelitian, dan kesabaran tercermin dari proses pembuatannya yang memerlukan ketekunan, ketelitian, dan kesabaran. Tanpa nilai-nilai tersebut tidak mungkin akan terwujud sebuah tenun tapis yang indah dan sarat makna.

Selain mengandung nilai-nilai karakter dan budaya, motif yang terdapat pada Tapis Lampung juga memiliki makna tersendiri. Terciptanya motif pada kain dilandasi oleh penguasaan sistem pengetahuan mereka tentang lingkungan dapat 
merangsang manusia untuk menciptakan motif yang kemudian dicurahkan pada sumber kain. Dengan demikian maka kemampuan pengetahuan terhadap berbagai jenis tumbuh-tumbuhan divisualisasikan kedalam kain berupa motif tumbuhan.Motif tersebut disamping berfungsi sebagai hiasan, juga berfungsi sebagai informasi kebudayaan dalam wujud lambanglambang yang bermakna. Wujud tersebut adalah sebagai akibat dari kemampuan daya pikir manusia sebagai motorik baik mengorganisasikan maupun dalam memakainya.

Tapis Lampung memiliki 10 motif, dimana pada setiap motif terdapat filosofinya atau dengan kata lain terdapat makna kehidupan didalamnya. Berikut penulis uraikan filosofi motif tapis Lampungmenurut Putra (dalam Radar Lampung, 2 Maret 2016):

Motif Pilin Berganda. Motif ini bermakna bahwa suatu peringatan untuk kita janganlah memutuskan ke muaghian. Oleh karena itu, jagalah hubungan dengan sanak famili untuk tetap harmonis baik itu dengan sanak famili yang dekat maupun sanak famili yang jauh dari kita.

Motif Belah Ketupat. Motif Tapis Lampung dengan Belah ketupat ini mengandung makna kebersamaan. Apabila kita mendapatkan kelebihan rezeki, sesungguhnya sebagian tersimpan dalam rezeki itu adalah hak orang lain.

Motif Pucuk Rebung. Dalam Motif Tapis Lampung Pucuk Rebung ini atau lebih kita kenal dengan tunas bambu, melambangkan hubungan kekeluargaan dalam sebuah keluarga yang tidak dapat dipisahkan antara yang satu dengan yang lainnya. Oleh karena itu, hendaklah kita selalu untuk tolong menolong dalam hal kebaikan, serta saling menegur apabila ada salah satu diantara keluarga kita yang melakukan kesalahan.

Motif Geometris. Motif Geometris menggambarkan bahwa tegaknya lembaga adat dapat terwujud apabila didukung oleh semua pihak yang berperan serta sesuai dengan keahliannya masing masing.

Motif Tajuk Bergaya. Motif Tajuk Bergaya ini menandakan mudah bergaul dan tetap menjaga piil pesenggighi(malu melakukan pekerjaan hina menurut agama serta memiliki harga diri).

Motif Bunga. Tapis Lampung dengan Motif Bunga memiliki makna setiap pekerjaan dan perbuatan haruslah rapih dan indah. Sehingga memiliki nilai estetika yang tinggi.

Motif Bulung Kibang. Dalam Motif Bulung Kibang ini melambangkan bahwa kemampuan merantau kelak akan pulang juga ke kampung halaman dengan membawa keberhasilan dan dapat mengangkat derajat dan martabat keluarga.

Motif Pohon Hayat/Kehidupan. Motif Tapis Lampung ini juga melambangkan kemampuan seseorang dalam menempatkan diri di dalam sebuah kaum yang dapat menentukan jalan hidupnya.

Motif Burung. Motif ini melambangkan kebebasan. Bebas dalam menentukan pilihan asalkan tidak bertentangan dengan adat istiadat, berperilaku sopan santun dan ramah.

Motif Naga. Motif Tapis Lampung dengan gambar naga ini menggambarkan sifat pemimpin, selain gagah, berwibawa juga harus sabar, adil dan bijaksana. 
Tapis Lampung sebagai Identitas Bangsa

Seperti halnya suku bangsa lain di Indonesia, Lampung sebagai masyarakat dengan peradaban yang cukup tua juga memiliki atribut khas yang mencerminkan masyarakatnya. Salah satunya Kain Tapis sebagai kain tradisional Lampung. Kain katun dengan warna gelap merupakan bahan dasar tapis Lampung yang selanjutnya kain ini disulam menggunakan benang emas.

Tapis merupakan produk kebudayaan dengan nilai tinggi. Bagi masyarakat Lampung, Tapis tidak hanya berupa pakaian adat, melainkan juga atribut sosial yang mencerminkan siapa pemakainya. Ragam hias Kain Tapis merupakan penggambaran dari simbol-simbol yang dianggap sakral oleh masyarakat Lampung. Misalnya bentuk perahu, tulisan arab serta flora dan fauna tertentu seperti gajah, naga dan beberapa jenis tumbuhan sulur.

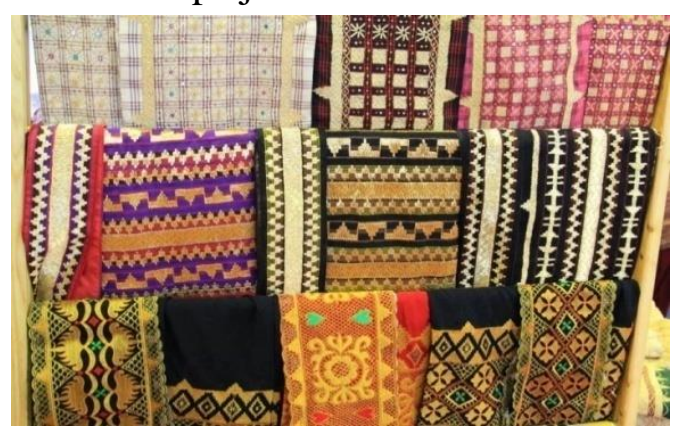

Gambar 1. Foto Kain Tapis Lampung (Sumber Foto dari Ramadhan, 2015)

Sebagai daerah yang memiliki atribut khas yang tradisional, masyarakat Lampung mempunyai semboyan, yaitu "Lampung Bertapis Helau". Dalam bahasa Indonesia, semboyan tersebut diartikan bahwa Lampung merupakan provinsi yang penduduknya menggunakan Kain Tapis sebagai pakaian adat yang indah. Tapis Lampung memang merupakan hasil seni yang indah sesuai semboyan tersebut.Sebagai karya seni, pengerjaan
Tapis dilakukan para wanita. Dengan penuh teliti dan hati-hati, mereka meyulam Tapis hingga berbentuk kain sarung indah. Tapis biasanya digunakan saat acara-acara adat seperti pernihakan dan pemberian gelar pada masyarakat Lampung. Tapis merupakan komoditi unggulan masyarakat Lampung. Pembuatan Tapis masih berdasarkan cara adat tradisional hingga kini. Kain Tapis hanya diproduksi secara manual dengan cara ditenun. Waktu yang dihabiskan bisa seminggu bahkan sebulan. Belum lagi kerumitan dari ragam hias yang harus dibuat. Itu semua berpengaruh terhadap tinggi rendahnya kesulitan penenun dalam membuat Tapis.

Kain Tapis adalah salah satu warisan budaya masyarakat Lampung. Kain Tapis sudah sangat terikat dengan kebudayaan masyarakat Lampung. Kain Tapis menjadi satu kesenian tradisional Lampung dalam kaitannya dengan kehidupan masyarakat dan hubungan dengan pencipta alam semesta. Kain Tapis dapat menggambarkan strata-strata sosial dari masyarakat Lampung, yang menunjukkan posisi sebagai pengantin, istri kepala suku, keluarga pengantin,

dan lain-lain. Dari Kain Tapis, bisa menjelaskan identitas seseorang dalam masyarakat adat Lampung, terutama dalam upara perkawinan adat.

Dalam era globalisasi pasar bebas saat ini, Kain Tapis dapat dimanfaatkan untuk mengangkat nilainilai tradisi, dan juga dapat memperkenalkan budaya masyarakat Lampung, menguatkan Indonesia sebagai Negara dengan kekayaan budaya (dan kerajinan tradisionalnya), dan juga sebagai bagian dari dialog antara Indonesia dengan dunia. Oleh karena itu, Kain Tapis dapat memiliki manfaat bagi Indonesia di era MEA 2016. Artinya, Kain Tapis menjadi 
identitas bangsa dan menjadi salah satu bagian dari kekayaan budaya Indonesia untuk dikenal bangsa-bangsa lain. Kain Tapis dapat menjadi komoditi unggulan bagi masyarakat Lampung khususnya dan bagi Indonesia pada umumnya. Pemilihan Kain Tapis sebagai komoditi utama pada era MEA, karena pertimbangan potensi nilai dan keindahannya untuk diterima dalam pergaulan budaya dan juga pasar modern.

Kain Tapis Lampung merupakan salah satu identitas bangsa Indonesia, karena tapis Lampung sudah dikenal di masyarakat internasional. Hal ini dapat dibuktikan dengan dilaksakannya pameran Kain Tapis Lampung oleh DWP KBRI Canberra di Australia, ini merupakan bagian dari upaya untuk lebih memperkenalkan berbagai produk kain, kerajinan dan seni tradisional serta kuliner dari berbagai daerah di Indonesia.

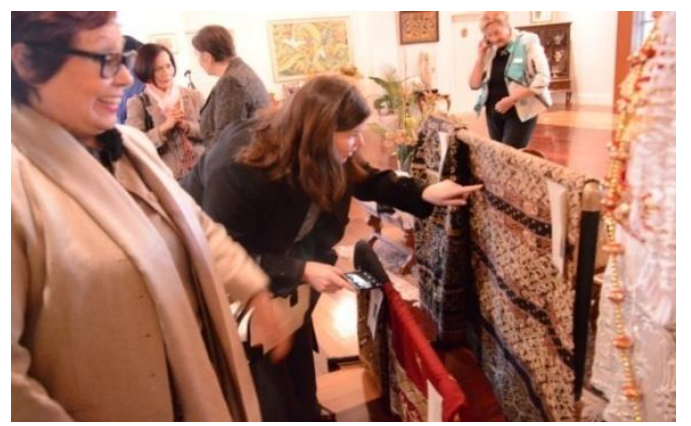

Gambar 2. Kain Tapis Lampung yang dipamerakan di Australia (Sumber Foto dari Wawandhi, 2015)

Berkat promosi aktif DWP KBRI Canberra selama ini, saat ini jumlah masyarakat Australia yang ingin mengenal lebih dekat kesenian dan kerajinan tradisional Indonesia semakin meningkat yang antara lain tercermin dari kian banyaknya anggota WIC Indonesian Circle dan selalu padatnya setiap kali ada acara promosi budaya Indonesia di lingkungan KBRI Canberra.
Selain pameran di Australia, Tapis Lampung juga memukau masyarakat dunia, ketika dipakai pada acara upacara pembukaan olimpiade di Brazil. Kostum tradisional yang dipakai kontingen Indonesiasaat parade upacara pembukaanOlimpiade 2016 Rio de Jenairo, membuat banyak orang di seluruh penjuru dunia terpukau dan memuji keindahannya. Salah satu yang menarik perhatian adalahkemewahan pakaian tradisional asal Lampung yang dipakai yaitu tapis Lampung.

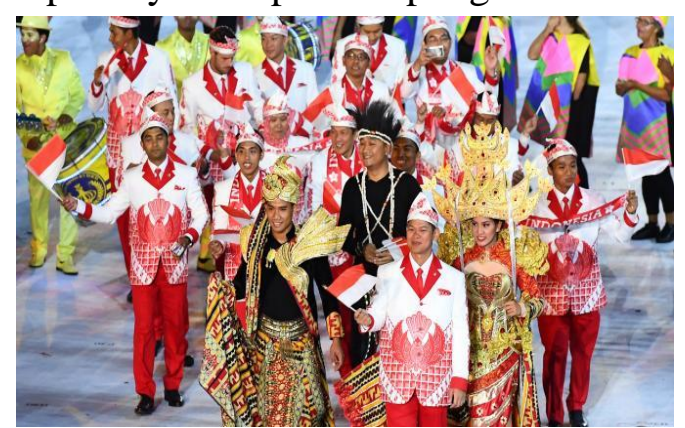

Gambar 3. Foto Penggunaan Kain Tapis Lampung pada Upacara Pembukaan Olimpiade 2016 Rio de Jenairo (Sumber Foto dari Trisna, 2016)

Berdasarkan uraian di atas, maka jelas bahwa Kain Tapis Lampung menjadi identitas bangsa Indonesia dan menjadi salah satu bagian dari kekayaan budaya Indonesia yang sudah dikenal bangsa-bangsa lain.Nilai dan keindahannya dapat menguatkan Indonesia sebagai Negara dengan kekayaan budaya, sehingga diterima dalam pergaulan budaya dan juga pasar internasional.

\section{SIMPULAN}

Berdasarkan pembahasan, maka dapat disimpulkan bahwa Tapis adalah salah satu jenis kebudayaan masyarakat Lampung. Tapis merupakan warisan leluhur nenek moyang masyarakat Lampung berupa kain sarung yang ditenun. Tapis merupakan simbol dari kebudayaan masyarakat Lampung, 
tidak hanya sebagai pakaian semata. Setiap motif yang dimunculkan dari Kain Tapis melambangkan makna yang tersirat mengenai nilai-nilai yang berkaitan dengan falsafah hidup hingga perekonomian masyarakat Lampung. Nilai-nilai yang terdapat dalam Tapis Lampung diantaranya nilai sakral, nilai stratifikasi sosial, nilai sejarah dan pemahaman terhadap alam. Selain nilai yang berkaitan dengan falsafah hidup, pembuatan Tapis Lampung juga mengandung nilai-nilai karkter, seperti nilai kreativitas dan inklusivitas, nilai ekonomis, nilai kerjasama, dan nilai ketekunan, ketelitian, dan kesabaran. Apabila mengamati lebih mendalam setiap motif yang digunakan dalam kain tapis, maka kita dapat memahami penenun atau pengrajin kain tapis seolah menggambarkan bagaimana kehidupan masyarakat Lampung dan seperti apa budaya yang ada didalamnya.Kain tapis adalah budaya material yang merupakan identitas sosial masyarakat Lampung karena pembedaan kode sosial berupa motif dalam kain Tapis Lampung menunjukkan perbedaan status sosial. Selain itu, kain Tapis Lampung juga merupakan salah satu identitas bangsa Indonesia, karena tapis Lampung sudah dikenal di masyarakat internasional.

\section{DAFTAR PUSTAKA}

Adisusilo, Sutarjo.

(2012).

Pembelajaran

Nilai-nilai

Karakter: Konstruktivisme dan VCT sebagai Inovasi Pendekatan Pembelajaran Afektif. Jakarta: PT Raja Grafindo Persada.

Aunillah, Nurla, I. (2011). Paduan Menerapkan Pendidikan Karakter di Sekolah. Yogyakarta: Laksana.
Fatchan, A. (2009). Metode Penelitian Kualitatif. Kediri: Pustaka Pesantren

Gunawan, H. (2012). Pendidikan Karakter, Konsep dan Implementasi. Bandung: Alfabeta.

Hamy, S., Sutyawan S \& Debbie. (2011). Sulam Tapis Lampung. Jakarta. Gramedia Pustaka Utama.

Harris, M. (1999). Theories of Culture in Postmodern Times. New York: Altamira Press.

Isbandiyah. (2015). Pendidikan Karakter Sebagai Upaya Memperkuat Jatidiri Bangsa di Era Masyarakat Ekonomi ASEAN. Prosiding Seminar Pendidikan Nasional dengan Tema Peluang dan Tantangan Dunia Pendidikan dalam Era Masyarakat Ekonomi ASEAN (MEA). Palembang: Universitas PGRI Palembang.

Kaelan. (2010). Pendidikan Kewarganegaraan. Yogyakarta: Paradigma

Kohn, H. (1984). Nasionalisme: Arti dan Sejarahnya. Jakarta: Erlangga.

Lestari, D., A., P. (1999). Membina Kreativitas Siswa SLTP dalam Sulam Tapis Lampung. Lampung.

Megawangi, R. (2004). Pendidikan Karakter: Solusi yang Tepat untuk Membangun Bangsa. Jakarta: BP Migas.

Permendagri Nomor 39 Tahun 2007 Pasal 1 Tentang Pedoman Fasilitasi Organisasi Kemasyarakatan Bidang Kebudayaan,Keraton, dan Lembaga Adat dalam Pelestarian dan Pengembangan Budaya Daerah. 
Putra, A. (2016). Mengenal Lebih Dekat dengan Filosofi Motif Tapis Lampung.Radar Lampung pada Hari Rabu Tanggal 2 Maret 2016. (Online) diakses dari http://golekteknoblogspot.com, pada tanggal 24 November 2016.

Ramadhan, B. (2015). Keindahan Kain Tenun Tapis dari Lampung. (Online) diakses dari https://www.goodnewsfromindo nesia.id, pada tanggal 24 November 2016.

Ratna, N., K. (2005). Sastra dan Cultural Studies: Representasi Fiksi dan Fakta. Yogyakarta: Pustaka Pelajar.

Samaludin, M., M. (2017). Identitas Naional dalam Buku Teks Pelajaran Sejarah SMA. JPIS: Jurnal Pendidikan Ilmu Sosial, 26 (2), Desember 2017.

Samani, M \& Hariyanto. (2012). Konsep dan Model Pendidikan Karakter. Bandung: PT Remaja Rosdakarya.

Saryono \& Anggraeni. M., D (2011). Metodologi Penelitian Kualitatif dalam Bidang Kesehatan. Yogjakarta: Nuha Medika.

Setiyawan, A. (2012). Budaya Lokal dalam Perspektif Agama: Legitimasi Hukum Adat ('Urf) dalam Islam. Jurnal ESENSIA, XIII (2) Juli 2012.

Sujadi, F. (2012). Lampung Sai Bumi Ruwa Jurai. Jakarta: Cita Insan Madani.

Sulistyowati, E. (2012). Implementasi Kurikulum Pendidikan Karakter.
Sumaatmadja, N. (2002). Pendidikan Pemanusiaan Manusia Manusiawi. Bandung: Alfabeta.

Tilaar, H. A.R. (2000). Pendidikan, Kebudayaan, dan Masyarakat Madani Indonesia. Bandung: Rosdakarya.

Trisna, V., Y. (2016). Foto Kostum Ini Buat Indonesia Dipuji Pada Pembukaan

Olimpiade.(Online), diakses dari https://www.bola.com, pada tanggal 24 November 2016.

Wawandhi, R. (2015). Decak Kagum Warga Australia Untuk Tapis Lampung. (Online), diakses dari https://www.jejamo.com, pada tanggal 24 November 2016. 